\title{
EVOLUTION OF AGRICULTURAL MARKETING INSTITUTIONS: A CHANNEL APPROACH
}

\author{
Matthew T.G. Meulenberg ${ }^{1}$
}

\section{Introduction}

The marketing channels for agricultural and food products are made up of a number of companies, such as, breeders, mixed feed producers, farmers, traders, processors and retailers. The role of these companies in the marketing channel is as a marketing institution, that is an organisation which is engaged in the marketing planning and the marketing functions related to a specific product. Agricultural marketing channels sometimes include special marketing institutions, such as, auctions, marketing cooperatives, marketing boards, commodity boards and futures markets.

The need for market orientation in Westem agricultural markets has stimulated the coordination of marketing operations in the channel. Many agricultural marketing channels have become vertical marketing systems, also called marketing chains, which are characterized by coordinated marketing policies. Agricultural marketing institutions must respond appropriately to the need for coordinated marketing policies in the channel. This requires an understanding of marketing institutions as actors in the agricultural marketing channel.

Marketing theory has contributed a great deal to our knowledge of marketing institutions. Concepts and theories from industrial economics are also helpful in this respect. However, the growing importance of marketing chains, or vertical marketing systems, in agricultural marketing calls for a better understanding of marketing institutions as actors in the channel. This article contributes to this by reviewing the literature on marketing institutions as an element of the marketing channel and by proposing a framework for the analysis of agricultural marketing institutions as actors in the marketing channel for a product. Needless to say, our contribution borrows heavily from the relevant marketing literature, in particular, the literature on marketing channels (e.g., Bucklin, 1970; Mallen, 1977; Sheth, et al., 1988; Stern and El-Ansary, 1992).

Our paper is organized as follows. First, some aspects of agricultural marketing institutions as actors in marketing channels are presented and environmental trends which influence agricultural marketing channels are described. Some important 
contributions from marketing theory and industrial economics to the discipline of marketing channels are reviewed. Next a framework for the analysis of marketing institutions as actors in marketing channels is proposed and its usefulness for the analysis of agricultural marketing institutions is elaborated upon.

\section{Marketing institutions in agricultural marketing channels}

Basic characteristics of marketing institutions as actors in agricultural marketing channels. In the marketing of agricultural products functions are performed, which are traditionally classified as exchange functions, physical functions and facilitating functions (Clark and Clark, 1947; Kohls and Uhl, 1990). The shift towards a consumer orientation has stimulated marketing management in agricultural marketing (Meulenberg, 1994, p.3), that is, the planning, implementation and control of the marketing mix with respect to the needs and wants of consumers. Agricultural marketing plans and marketing functions are programmed and executed by producers, traders and/or other marketing institutions:

- price formation, buying and selling are executed by producers and distributors. Special marketing institutions, such as auctions (price discovery) and futures markets (price-risk management) facilitate the price formation process.

- product development, traditionally a task of breeders, farmers and food industry, is increasingly becoming an activity of big retail food chains, too. In some agricultural sectors, special research institutes, financed by government and/or by industry, do product research which is beneficial to all companies in the industry. Industry bodies and government establish and monitor grading and sorting schemes for agricultural products, and in particular, for agricultural commodities.

Promotion of agricultural and food products not only includes product and brand promotion by individual companies, but also generic promotion by promotional boards. Agricultural promotional boards are important in many countries, but promotion by individual companies is gaining importance because of a trend towards bigger companies in the agribusiness and food industries, which prefer to promote their own products and brands instead of spending funds on generic promotion.

- distributive tasks in agricultural marketing are fulfilled by producers, wholesalers and retailers, as well as by special marketing institutions, such as, marketing cooperatives. Logistics firms have an important task in physical distribution.

Agricultural marketing institutions differ both with respect to the type of marketing functions performed and with respect to the degree of involvement in the marketing process. For instance, many food companies are full fledged marketers of branded products, while food brokers only mediate between buyers and sellers, and agricultural auctions essentially facilitate the price discovery process. 
Various agricultural marketing institutions have extended their activities from basic marketing tasks into new fields. For instance, Dutch horticultural auctions started out as institutions which facilitated price discovery, but quite soon became logistical centres and extended their marketing tasks into other fields, such as, promotion, minimum price schemes, sorting and grading and product quality (Meulenberg, 1989). They probably will end up as marketing cooperatives, with limited sales by auction. Food retailers have evolved from distributors to sophisticated marketers. Interestingly, marketing institutions take up new functions not only because of their special expertise, but sometimes also because of their strong channel power. The example of Dutch cooperative horticultural auctions is a case in point.

The performance of marketing tasks in agricultural marketing channels is increasingly based on good relationships between marketing institutions. These relationships are based on joint planning and trust, and are sometimes formalized in contracts or integration. Strong relationships between agricultural marketing institutions are extremely important in view of the present need for the coordination of marketing plans at the various stages of the marketing channel. This is, in particular, relevant for the marketing of fresh produce, such as, fresh meat, fruit and vegetables and flowers.

\subsection{Trends in marketing institutions}

The role of marketing institutions in the channel is influenced by a number of trends, both external and internal to the marketing channel. We briefly review the impact of some major trends.

\subsubsection{External trends}

Achrol and Stem (1988) concluded in an analysis of the way environmental factors affect decision making uncertainty in channels that, “....four dimensions - diversity among consumers, dynamism, concentration, and - should be included in future research on the effects of environments on intrachannel variables." Environmental trends, such as socio-cultural, competitive, ecological, technological and political trends, greatly influence the role and function of marketing institutions in agricultural marketing channels. We briefly summarize the impact of these trends.

Socio-cultural developments. Socio-cultural developments have a strong impact on consumer behavior and consequently on agricultural marketing channels. The following developments seem particularly relevant.

- Demography. The greying of western populations stimulates the importance of food marketing channels which serve institutional households. Small households and women in the workforce reinforce consumer needs for distributive services, such as, product packaging and longer store opening hours. The concentration of the population in urban centres and increasing consumer mobility have a positive impact on the size of food outlets and 
their locations. The trend towards multicultural societies in Western countries increases the opportunity and need for broader retail product assortments.

- Consumer behaviour. The increasing importance of health, freshness, convenience and variety in food consumption advances wider and deeper food assortments in supermarkets, and places greater demands upon logistical efficiency. The food consumption habit of grazing has made product availability to consumers a more important issue.

Competition. Competition is increasing in Western agricultural and food markets. Markets are more open as a result of the Maastricht treaty and the GATT agreement. Advances in logistics and information technology enlarge international competition in food marketing. Retail chains internationalize their purchasing of food products. For instance, retail chains purchase wines from Chili, South Africa or Australia, and fresh vegetables from Morocco and flowers from Kenia or Colombia.

Ecology. Societal concerns about sustainability foster "green" logistics, with respect to among others, the mode of transport and the packaging. It also stimulates new marketing outlets for organic food.

Technology. Technological developments in, in particular information technology and transport, create opportunities for improvements in efficiency in agricultural marketing channels.

Politics. The overriding trend in the political environment for agricultural marketing channels is "less government interference and more market access". In contrast to this general trend, government intervention is increasing because of environmental problems resulting from processes in agricultural marketing channels.

The responses of marketing channels to changes in the external environment are often initiated by a specific marketing institution in the marketing channel, for instance, a food retailer. In line with Von Hippel's theory, one might hypothesize that the marketing institution, which expects the greatest profits from an innovation, will trigger that innovation in the marketing channel (Von Hippel, 1988).

\subsubsection{Internal factors}

Experiences, research findings and creative ideas about marketing institutions also contribute to innovations in the channel. This type of innovation is becoming more frequent because of the concentration among companies in the food industry and in food retailing. Big companies in the agricultural marketing channel are focusing on quality and innovation, are very demanding of their suppliers and are spending more money on research and development. 


\section{Theories about marketing institutions as actors in the marketing channel}

Many theories about marketing channels are concerned with marketing institutions. Not only marketing theory but also industrial organisation theory, contributes to insights in the role of marketing institutions in marketing channels.

\subsection{Marketing theories about marketing channels which are relevant to marketing institutions}

Channel formation and the role of marketing institutions in the channel is a central topic for marketing theory. The following review of highlights in this field is structured using the classification of marketing schools as proposed by Sheth $e t a l$. (1988).

The Commodity School developed product classification systems which seem to be relevant to marketing channel formation. Copeland's (1923) classification of convenience goods, shopping goods and specialty goods and its extension by Holbrook and Howard, by adding a fourth class, preference goods, (quoted by Sheth et al., 1988, p. 45) have implications for consumer shopping habits and, as a result for the location of retail outlets. Aspinwall (1962) argued that the type of product influences the channel structure: an indirect marketing channel, i.e., a channel including a middleman, will emerge between a producer and a consumer if the good has a high replacement rate and a low gross margin, rate of adjustment, consumption time, search time, and vice versa. Miracle (1965) extended Aspinwall's classification scheme. Rangan et al. (1992) proposed a more comprehensive list of eight selection criteria, which are related to product, information, service and logistics.

The creators of the functional school focus on activities needed to execute marketing transactions (Sheth et al., 1988, p. 53), but do not pay special attention to the institutions which perform these functions. Actually, in this school of thought, the marketing channel structure is a corollary of the performance of marketing functions.

The regional school of thought, concerned with "marketing as an economic activity designed to bridge the geographic, or spatial, gaps between buyers and sellers (Sheth et al., 1988,p 60), has produced models on the attractiveness of shopping centres and stores, and on interregional marketing. However, these models make no explicit reference to the analysis of marketing institutions and the channel structure.

In the functionalist school, which conceives marketing of "as a system of interrelated structural and interdependent dynamic relationships" (Sheth et al., 1988, p. 86) concepts are proposed which are relevant to a better understanding of the channel structure and of the marketing institutions. In particular, according to the "sorting principle", sorts by which a heterogeneous supply is matched with heterogeneous demand, and "transvection", the sequence of exchanges and 
transformations from raw material to final product (Alderson, 1954, 1965), are relevant concepts for channel formation since they concern functions often carried out by middlemen.

In the managerial school of thought the planning of the marketing mix, in particular the place or distribution, has implications for the structure of marketing channels, and for that reason, for the role of marketing institutions. However, no explicit attention is paid to the structure of marketing channels and marketing institutions as such.

The institutional school, focusing on "the organisations that actually perform the functions required to move the goods from the producer to the consumer" (Sheth et al., 1988, p. 74), contributes a great deal to the theory of channel formation and of marketing institutions. Many scholars have analyzed marketing institutions from the efficiency point of view (Alderson, 1954; Stigler, 1951; Mallen, 1953, 1977; McCammon, 1963; Bucklin, 1965, 1970; Vaile et al., 1952). Attention has been paid to the transfer of marketing functions in the marketing channel from one marketing institution to another out of efficiency reasons. Stigler's (1951) concept of vertical specialisation and Mallen's (1953) "spin off" concept are cases in point. Bucklin (1970) and Mallen (1977) have developed classification systems to describe marketing channels.

In the case of perfect competition costs ultimately determine the channel structure. When the market structure differs from perfect competition, which increasingly happens to be the case in agricultural markets, effectiveness and/or equity are important criteria, too. Many studies which emphasize marketing efficiency as a criterion for channel structures have also included the effectiveness of marketing as a criterion. For instance, while Bucklin accentuates costs as a criterion for channel formation, his concepts and analyses, such as "Postponement and speculation" (Bucklin, 1965), and the variables assortment and waiting time (Bucklin, 1966), are demand-related as well.

Etgar and Zusman (1982) propose a model of marketing channel formation that assumes that wholesalers maximize profits by buying, processing and selling information. Models from management science (see Lilien et al. 1, 1992, pp. 415-431; Stern, El-Ansary, 1992, pp. 304-311) analyze channel structures by focusing on the relationship between a profit maximizing manufacturer and a retailer under different assumptions about: a) the degree of integration (the retailer is integrated with the manufacturer or is independent); b) the type of market structure (the manufacturer is a monopolist or not; and sells to an exclusive retailer or not (McGuire and Staelin, $1983)$ ); c) the profit function of the manufacturer (costs of retail services are fixed, marginal costs of production and retailing are stable, the demand function is linear or non linear); d) the profit-sharing arrangement (Jeuland and Shugan, 1983).

The organisational dynamics school of thought analyzes marketing channels from 
the behavioral point of view. Initiated by Stern (1969), contributions from this school concentrate their analysis upon power, conflict and satisfaction in marketing channels. A great diversity of research questions has been addressed, such as: "What is the impact of different types of power sources - coercive versus noncoercive - on conflict in the channel of distribution?" (Hunt and Nevin, 1974); "What factors affect the probability that the less powerful channel member will comply with the wishes of the more powerful channel member?" (Hunt et al., 1987); Can the power of a channel leader "be offset by the countervailing power available to the channel members?" (Etgar, 1976).

Special attention has been devoted to the relationship between companies in the marketing channel. Coordination between marketing institutions in the marketing channel has been analysed extensively. For instance, Celly and Frazier (1996) investigated outcome- and behaviour-based coordination efforts in the relationship between supplier personnel and distributors. They established a strong positive relationship between environmental uncertainty and behaviour-based coordination efforts.

Vertical marketing systems are classified on the basis of the strength of the relationship, such as, administered, contractual and corporate systems (Stern and ElAnsary, 1992). Much attention is paid to franchising. Various authors stress "resource constraints" as the argument for using franchising, while others emphasize the "incentive" argument, that is, the need to motivate franchisees to put sufficient effort into their business (see, e.g., Lafontaine and Kaufmann, 1994). Anderson and Weitz (1989) conclude that interpersonal relationships ensure the continuity of industrial channel dyads. Kumar et al. (1995) demonstrate that, "with increasing interdependence asymmetry, the dealer's trust in and commitment to the supplier decline while interfirm conflict increases." Trust between companies in the marketing channels has become an important research subject (see, Geyskens and Steenkamp, 1995).

Behavioral research on marketing channels has stimulated the development of frameworks for the analysis of marketing channels. Stern, Reve (1980) developed a framework which takes into account economic and behavioral, and internal and external respectively, factors which influence the structure of the marketing channel. Frazier (1983) proposes a framework for interorganisational exchange behavior in marketing channels, which structures the exchange relationship of a firm with a target firm through the successive stages of initiation, implementation and review. Dwyer et al. (1987) outline a framework for the evolution of buyer-seller relationships through five phases from awareness until dissolution.

Other schools of thought in marketing, as distinguished by Sheth, et al. (1988), have contributed little to theories and concepts on marketing channels and marketing institutions: the buyer behovior school, which focuses on customers in the market place; the activist school, which is concerned with issues of consumer welfare and 
consumer satisfaction; the macromarketing school, which studies the role and impact of marketing activities and marketing institutions on society and vice versa: the systems school of thought, which analyzes marketing from a systems point of view; and the social exchange school, which focuses on the foundations of social exchange.

\subsection{Industrial organisation theory and marketing channels}

Transaction costs theory (Williamson, 1975, 1985), an important area of in industrial organisation theory, is frequently used in the analysis of marketing channels. Entrepreneurial characteristics, such as, opportunism, and bounded rationality, and transaction characteristics, such as, asset specificity, uncertainty and complexity, frequency and governance costs appear to be useful concepts for the analysis of the governance structures in the channel. For instance, Gassenheimer et al. (1996) concluded, on the basis of an analysis of fast food franchisees in the U.S., that, "communication moderates the impact of opportunism on satisfaction," and "A significant negative relationship remains between opportunism and franchise satisfaction."

While asset specificity is traditionally considered to be an exogenous variable in the transaction costs approach, Riordan and Williamson (1985) introduce asset specificity as a choice variable in the decision process for a governance structure. In explaining the structures of conventional marketing channels, Heide and John (1988) extend the basic transaction costs model with insights from dependence theory.

Conclusion. The marketing channel is an important topic in marketing theory. However, theories on the evolution of agricultural marketing institutions as actors in the marketing channel from producer to retailer are less numerous. Actually, this evolution is becoming increasingly important in agriculture in view of dynamic changes in the markets. Therefore, in the next section, a framework is proposed for identifying the strategic position of a marketing institution as an actor in the channel.

\section{A framework for the analysis of the strategic position of marketing institutions in the marketing channel}

We suggest the following hierarchical classification as a useful instrument for better understanding the role of marketing institutions in agricultural marketing channels:

a) strategic marketing institutions, which determine the basic marketing strategy of the product involved and, for that reason, the core characteristics of the marketing mix;

b) tactical marketing institutions, which plan and implement tactical marketing policies within the framework of the basic marketing strategy, for example, an agent or dealer operating on behalf of his principal; 
c) facilitating marketing institutions, which facilitate marketing processes, without being involved in marketing decision making with respect to the product, for example an auction or a futures market;

d) facilitating institutions, which offer services to marketing institutions in the channel, without getting involved in the marketing process as such, for example freight companies.

Whether a marketing institution belongs to one of these categories depends on its involvement in the:

- marketing object, that is the channel flows,

- marketing goals in relation to channel flows,

- marketing functions in relation to channel flows,

- relationships with other marketing institutions.

This argument will be elaborated on below.

4.1. The classification of marketing institutions on the basis of their involvement in channel flows

Marketing institutions are concerned with different flows in the channel: property flows, product (service) flows, and information flows (Mallen, 1977; see also Bucklin, 1970). The involvement of marketing institutions in these flows differs. We propose the following criteria for classifying marketing institutions.

a) Property flow.

- taking title to a good is a necessary condition for being a strategic marketing institution; product ownership is essential for making strategic marketing decisions.

- directing property flows is a necessary condition for being a tactical marketing institution, for example an agent marketing a product on behalf of his principal,

- having no influence on property flows is a characteristic of facilitating marketing institutions, such as auctions and futures markets, or facilitating institutions, such as freight companies.

b) Product flow.

- determining the "core benefits" of a product is a characteristic of strategic marketing institutions;

- determining at least some augmented product benefits is characteristic to a tactical marketing institution;

- influencing product flow direction, but not product benefits, is characteristic for facilitating marketing institutions, such as, auctions houses;

- involvement in physical product flows without directing product flows from the marketing point of view is characteristic to facilitating institutions, such as, logistics companies. 
c) Information flow.

- All marketing institutions in agricultural marketing channels are involved in information flows. The type of information transfer is related to the role of a marketing institution with respect to property and product flow.

4.2. Classification of marketing institutions on the basis of their involvement in marketing goals

The involvement in marketing goals differs between institutions:

- developing long-term marketing goals is a characteristic of strategic marketing institutions.

- developing short-term marketing goals only, for example the marketing target of a special promotional campaign is a characteristic of tactical marketing institutions, such as, agents operating within the bounds of the long-term strategy of their principal.

- developing goals with respect to the performance of a specific marketing function or operation, for example price discovery, is a characteristic of facilitating marketing institutions.

- no involvement in marketing goals with respect to a product but being concerned with the efficiency of marketing operations is a characteristic of facilitating institutions.

4.3. Classification of marketing institutions on the basis of involvement in marketing functions

Marketing functions fulfilled by a marketing institution are related to marketing objects and marketing goals. For this reason, there is an overlap between the classification rules related to marketing functions and those related to channel flows and goals:

- marketing institutions which carry out the function of developing the core product are strategic marketing institutions.

- marketing institutions which fulfil marketing functions within the constraints of the basic marketing strategy of the strategic marketing institution are tactical marketing institutions, for example dealers, agents, franchisees.

- marketing institutions which improve marketing effectiveness and efficiency without being a marketing partner in the exchange process are facilitating marketing institutions, for example auctions which improve price discovery or promotional boards which promote the generic product at the industry level.

- institutions which improve the efficiency of marketing institutions in the channel without being involved in marketing processes are facilitating institutions, for example market research companies or freight companies. 


\subsection{Classification of marketing institutions on the basis of their relationships in the marketing channel}

An important characteristic of a marketing institution is the relationship with other marketing institutions in the channel. The following aspects of the relationship between marketing institutions in a marketing channel seem important for characterising a marketing institution:

- the strength of the relationship may vary from no relationship at all (spot contract) to full integration (vertical integration).

- the strength of the relationship is positively related to the sophistication of the marketing plan in the channel and also the uncertainty and complexity and asset specificity of the marketing operations.

\section{Response of agricultural marketing institutions to a changing environment}

Many agricultural marketing institutions operate in rapidly changing markets. Therefore it is important that a marketing institution is aware of its actual and potential role in the channel. The proposed framework may be helpful in this respect and may be applied "ad hoc" to any agricultural marketing channel. Its special feature is that the strategic position of the marketing institutions is analyzed within the context of the agricultural marketing channel from producer to retailer. Also on the basis of the developed framework, some general hypotheses about the response pattern of marketing institutions are made.

Hypothesis 1. Changing marketing policies for an agricultural product may lead to the exclusion of a marketing institution from the channel. The probability that a marketing institution will be excluded increases in the sequence: a) strategic marketing institution, b) tactical marketing institution, c) facilitating marketing institution, d) facilitating institution.

This hypothesis is based on the presumption that:

a) the channel power of a marketing institution in the marketing channel of a product is decreasing in the sequence "strategic....facilitating institution."; and,

b) an institution in the marketing channel can be replaced more easily, when it delivers a less fundamental contribution to the marketing programme of the respective product.

Hypothesis 2. Strong relationships between marketing institutions have a positive impact on the adaptive potential of marketing institutions provided that these adaptations fit the basic marketing strategy of the core product.

This hypothesis is based on the following considerations. A strong relationship between marketing institutions in a channel decreases uncertainty and creates better opportunities to develop, communicate and implement specific responses to market 
changes in the channel. This is particularly important in the present agricultural and food markets, where the augmented product and customer services must be modified frequently because of changes in customer needs and in competition.

Hypothesis 3. Strong relationships between marketing institutions in a marketing channel may have a negative impact on the flexibility of marketing institutions when the basic marketing strategy of the core product is under threat.

This hypothesis is based on the argument that fundamental innovations have less opportunity to penetrate the channel when all marketing institutions in an agricultural marketing channel closely cooperate within the framework of a well-established marketing strategy for the core product.

Hypothesis 4 . The response of a marketing institution to market threats is influenced by the basic instinct of a marketing institution for survival.

This point is particularly relevant for strategic marketing institutions which have a strong power in the marketing channel. It stimulates politicking in response to market threats and creates short-term solutions which are not viable in the long run.

\section{Final remark}

The proposed classification scheme treats marketing institutions on the basis of objects, goals, functions and relationships. As such, a marketing institution is not necessarily one separate company, but may also be a joint effort between a number of different companies. Such an approach to a marketing institution fits with the one of Duddy and Revzan $(1953, \mathrm{pp} .16,17)$, the leading scholars of the institutional school where: "The institutional approach views the economic order as an organic whole made up of a great variety of economic structures, whose functioning is coordinated not only by prices and profit margins, but by management using authoritarian and persuasive techniques, by government regulation, and by social convention and custom."

\section{Notes}

1 Department of Marketing and Marketing Research, Wageningen Agricultural University, The Netherlands. 


\section{References}

Achrol, R.S. and L.W. Stern (1988), "Environmental Determinants of Decision-Making Uncertainty in Marketing Channels," Journal of Marketing Research, 25, February, pp. 36-50.

Alderson, W. (1954), "Factors Governing the Development of Marketing Channels," In: R. Clewett (ed.), Marketing Channels for Manufactured Products, Homewood Illinois: R.D. Irwin, Inc.,pp. 5-34.

Alderson, W. (1965), Dynamic Marketing Behavior: A Functionalist Theory of Marketing. Homewood Illinois: R.D. Irwin, Inc.

Anderson, E. and B. Weitz (1989), "Determinants of Continuity in Conventional Industrial Channel Dyads," Marketing Science, 8, 4, pp. 310-323.

Aspinwall, L.V. (1962), "The Characteristics of Goods Theory," In: W. Lazer and E.J. Kelley (eds.), Managerial Marketing: Perspectives and Viewpoints, Homewood Illinois: R.D. Inwin Inc., pp. 633-643.

Bucklin, L.P. (1965), "Postponement, Speculation and the Structure of Distribution Charnels," Journal of Marketing Research, 2, February, 26-31.

Bucklin, L.P. (1966), A Theory of Distribution Channel Structure, University of California, Berkeley. Institute of Business and Economic Research.

Bucklin, L.P., (1970), "The Classification of Channel Structures," In: L.P. Bucklin, (ed.), Vertical Marketing Systems, Glenview, Illinois, Scott, Foresman and Company, 18-31.

Bucklin, L.P. (ed.), (1970), Vertical Marketing Systems, Glenview, Illinois: Scott, Foresman and Company.

Celly, K.S. and G.L. Frazier (1996). "Outcome-Based and Behavior-Based Coordination Efforts in Channel Relationships," Journal of Marketing Research, 33 (May) 200-210.

Clark, F.E. and C.P. Clark, (1947), Principles of Marketing, New York, NY: The Macmillan Company, 3rd ed.

Copeland, M.T., (1923), "The Relation of Consumers' Buying Habits to Marketing Methods," Harvard Business Review, 1, April, 282-289.

Duddy E.A. and D.A. Revzan, (1953), Marketing: An Institutional Approach, Mc Graw-Hill Book Company, Inc., New York, NY: 2nd ed.

Dwyer, F.R., P.H. Schurr and S.Oh, (1987), "Developing Buyer-Seller Relationships," Journal of Marketing, 51, (April), 11-27.

Etgar, M. and P. Zusman, (1982), “The Marketing Intermediary as an Information Seller: A New Approach," Journal of Business, 55, 4, 505-515.

Etgar, M., (1976), "Channel Domination and Countervailing Power in Distributive Channels," Journal of Marketing Research, 8, August, 254-262.

Frazier, G.L. (1983), "Interorganizational Exchange Behavior in Marketing Channels: A Broadened Perspective," Journal of Marketing, 47 (Fall), 68-78.

Gassenheimer, J.B., D.B. Baucus and M.S. Baucus (1996), Cooperative Arrangements among Entrepreneurs: An Analysis of Opportunism and Communication in Franchise Structures," Journal of Business Research, 36, 67-79.

Geyskens, I. and J.E.B.M. Steenkarnp (1995), "Generalizations about Trust in Marketing Channel Relationships using Meta-analysis, Working Paper, Catholic University of Leuven.

Heide, J.B. and G. John (1988), "The Role of Dependence Balancing in Safeguarding Transaction-Specific Assets in Conventional Channels," Journal of Marketing, 52, January, pp. 20-35.

Hunt, S.D. and J.R. Nevin (1974), "Power in a Channel of Distribution: Sources and Consequences," Journal of Marketing Research, 11, (May), 186-193. 
Hunt, K. A., J.T. Mentzer and J.E. Danes (1987), "The Effect of Power Sources on Compliance in a Channel of Distribution: A Causal Model," Journal of Business Research, 15, 377-395.

Jeuland, A.P. and S. Shugan (1983), "Managing Channel Profits," Marketing Science, 2 (Summer), 239-272.

Kohls, R.L. and J.N. Uhl (1990), Marketing of Agricultural Products, New York, NY: Macmillan Publishing Company, 7th ed.

Kumar, N., L. Scheer and J.E.B.M. Steenkamp (1995), "The Effects of Perceived Interdependence on Dealer Attitudes," Journal of Marketing Research, 32 (August), 348-356.

Lafontaine, F. and P.J. Kaufmann (1994), "The Evolution of Ownership Patterns in Franchise Systems," Journal of Retailing, 70 (2), 97-113.

Lilien, G.L., P. Kotler and K.S. Moorty (1992), Marketing Models, Englewood Cliffs New Jersey: Prentice-Hall International Inc.

Mallen, B.E. (1963), "A Theory of Retailer-Supplier Conflict, Control and Cooperation," Journal of Retailing, 39, 24-32.

Mallen, B.E. (1977), Principles of Marketing Channel Management, Lexington, Mass: Lexington Books.

McCammon, B,, (1963), "Altemative Explanations of Institutional Change and Channel Evolution," In: A. Greyser, (ed.), Toward Scientific Marketing. American Marketing Association, pp. 477-490.

McGuire, T. and R. Staelin (1983), "An Industry Equilibrium Analysis of Downstream Vertical Integration," Marketing Science, 2, (Spring), 161-192.

Meulenberg, M.T.G., (1989) "Horticultural Auctions in the Netherlands: A Transition from "Price Discovery" Institution to "Marketing" Institution," Journal of International Food and Agribusiness Marketing, 1, (3/4) 139-165.

Meulenberg, M.(ed.) (1994), Food and Agribusiness Marketing in Europe, Binghamton, NY: The Haworth Press, Inc.,

Miracle, G.E. (1965), "Product Characteristics and Marketing Strategy," Journal of Marketing, 29, January, 18-24.

Rangan, V.K., M.A.J. Menezes and E.P. Maier (1992), "Channel Selection for New Industrial Products: A Framework, Method, and Application," Journal of Marketing, 56, July, 69-82.

Riordan, M.H. and O.E. Williamson (1985), Asset specificity and economic organization, International Journal of Industrial Organization, 3, pp. 365-378.

Sheth, J.N., D.M. Gardner and D.E. Garrett (1988), Marketing Theory: Evolution and Evaluation, New York, NY: John Wiley and Sons.

Stem, L.W. (1969), Distribution Channels: Behavioral Dimensions, Boston, MA: Houghton Mifflin Company.

Stern, L.W. and A.I. El-Ansary (1992), Marketing Channels, Englewood Cliffs, N.J.: Prentice Hall Inc., 4th ed.

Stem, L.W. and T. Reve (1980), "Distribution Channels as Political Economies: A Framework for Comparative Aralysis," Journal of Marketing, 44, (Summer), 3, 52-64.

Stigler, G.J. (1951), "The Division of Labor is Limited by the Extent of the Market," Journal of Political Economy, 54, 185-193.

Vaile, R.S., E.T. Grether and R. Cox (1952), Marketing in the American Economy, New York NY: The Ronald Press Company.

Von Hippel, E. (1988), The Sources of Innovation, Oxford: Oxford University Press.

Williamson, O.E. (1985), The Economic Institutions of Capitalism, New York, NY: The Free Press.

Williamson, O.E. (1975), Markets and Hierarchies: Analysis and Antitrust Implications, New York NY: The Free Press. 